DOI: https://doi.org/10.47405/aswj.v6i5.187

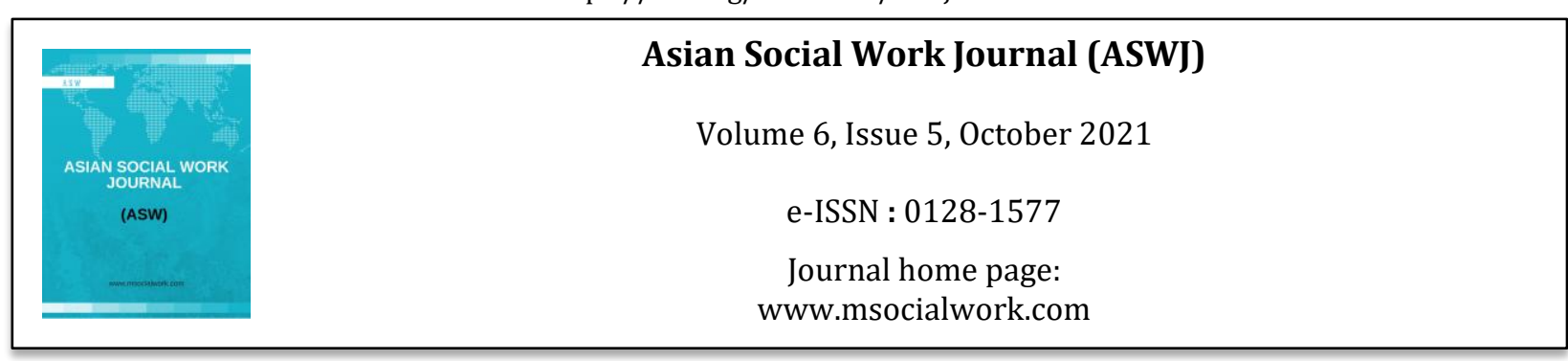

\title{
Kurang Celik Akal Pencetus Kepada Penagihan Dadah dalam kalangan Remaja
}

\author{
Nazri Daud1, Wan Anor Bin Wan Sulaiman'1 \\ 1Universiti Malaysia Sabah (UMS), Malaysia \\ Correspondence: Nazri Daud (dr.hero.superwira.z@gmail.com)
}

\begin{abstract}
Abstrak
Generasi muda merupakan modal insan yang amat penting kepada kesejahteraan dan pembangunan negara. Penglibatan golongan ini dalam aktiviti penyalahgunaan dadah telah mengancam keselamatan dan kemakmuran negara, malahan menjejaskan perkembangan sahsiah diri remaja ke alam dewasa. Oleh itu, kajian ini dijalankan bertujuan untuk menganalisis sejauh mana tahap 'celik akal' terhadap pengetahuan dadah dan kesannya dalam kalangan penagih remaja. Pengkaji mengaplikasikan pendekatan kualitatif melalui temu bual separuh berstruktur untuk memperoleh data. Kajian kes digunakan untuk meneroka dan memahami fenomena yang berlaku berdasarkan perspektif peserta kajian. Seramai enam orang remaja yang dikenal pasti mempunyai rekod penyalahgunaan dadah dan berusia di antara 13-18 tahun telah dipilih sebagai peserta kajian melalui persampelan bertujuan. Dapatan diperolehi menunjukkan 'celik akal' terhadap dadah yang dimiliki oleh penagih remaja adalah bersifat umum iaitu sekadar cuma mengetahui dadah itu bahan bahaya, menimbulkan ketagihan serta memberikan kesan fizikal dan psikologikal. Sumber maklumat dadah berdasarkan pengalaman mereka sendiri sebagai seorang penagih dadah sebelum ini dan melalui kawan-kawan. Kajian ini memberi implikasi ke arah memperkasakan modul pendidikan pencegahan dadah dalam kalangan remaja oleh pihak berkepentingan dengan menyebarluaskan segala maklumat melalui percambahan pengetahuan dadah dan kesan yang tepat serta betul sebagai instrumen utama untuk membanteras masalah penyalahgunaan dadah di Malaysia.
\end{abstract}

Kata Kunci: celik akal, penyalahgunaan dadah, remaja, kajian kualitatif

\section{Lack of Intelligence Causes Drug Addiction Among Teenagers}

\begin{abstract}
The young generation is a human capital that is very important to the well -being and development of the country. The involvement of this group in drug abuse activities has threatened the security and prosperity of the country, and even affected the development of adolescents' personalities into adulthood. Therefore, this study was conducted aimed at analyzing the extent of drug knowledge and its effects among adolescent addicts. Researchers applied a qualitative approach through semi structured interviews to obtain data. Case studies are used to explore and understand the phenomena that occur based on the perspectives of study participants. A total of six adolescents identified as having a record of drug abuse and aged between 13-18 years were selected as study participants through purposive sampling. Findings obtained show that the 'mental literacy' of drugs possessed by adolescent addicts is general in nature, that is, simply knowing that the drug is a dangerous substance, causes addiction and has physical and psychological effects. Sources of drug information based on their own experience as a previous drug addict and through friends. This study has implications
\end{abstract}


towards strengthening drug prevention education modules among adolescents by stakeholders by disseminating all information through the proliferation of drug knowledge and accurate and correct effects as the main instrument to combat drug abuse in Malaysia.

Keywords: mental literacy, drug abuse, adolescents, qualitative study

\section{Pengenalan}

Masalah penyalahgunaan bahan khususnya dadah merupakan gejala sosial yang masih lagi menjadi musuh utama negara. Hampir setiap hari media melaporkan tentang isu ini sama ada dari segi jenayah pengedaran dadah atau masalah penagihan dadah. Laporan Agensi Antidadah Kebangsaan (AADK) mendedahkan pada tahun 2017 terdapat 25,922 penagih dadah yang berjaya dikesan dibandingkan jumlah penagih dadah yang dikesan pada tahun 2020 seramai 128,325 di mana terdapat peningkatan yang ketara sebanyak 102,333 di mana golongan remaja juga terkesan di atas permasalahan ini. Menurut Agensi Anti Dadah Kebangsaan (AADK, 2020). Perangkaan ini mempunyai pandangan yang jelas dari segi peningkatannya penagihan dadah, merungkai di mana kepincangan atau kelemahan yang berlaku walaupun ada pelbagai program pencegahan dilakukan bagi membantu masyarakat khususnya golongan remaja mendapat maklumat mengenai kesedaran dan kesan bahayanya terhadap diri, keluarga, masyarakat dan negara. Strategi program-program mencegah lebih baik dari mengubati seumpama memaksa kita untuk sentiasa berfikir jauh ke hadapan mengenai pelan tindakan yang komprehensif untuk menanganinya dengan secara inklusif dan kolektif. Pelbagai usaha pro aktif telah dilaksanakan di mana pendekatan program pencegahan untuk menilai tahap pengetahuan, kefahaman, kemahiran dan membina jati diri pelajar-pelajar tingkatan 1 dan Tingkatan 5, yang melibatkan Perlaksanaan dan Keberkesanan Program Penyalahgunaan Dadah dalam Kalangan Pelajar di Sekolah-sekolah Menengah di gabungan Kota Kinabalu Sabah. Program pencegahan ini adalah untuk membendung ancaman penyalahgunaan dadah bagi pelajar-pelajar tersebut di mana satu program 'Seni Jauhi Dadah' (SEJADAH) telah dijalankan oleh Kementerian Pendidikan Malaysia (PPDa) dan kerjasama oleh Agensi Antidadah Kebangsaan (Wan Annor et al., 2018).

Jika menelusuri pula dari aspek umur bagi penagih remaja yang berusia 13 sehingga 18 tahun pada tahun 2017 adalah seramai 694 orang, manakala pada tahun 2020 penagihan remaja adalah seramai 2,556 orang, ini bermakna terdapat peningkatan yang amat ketara bagi pertambahan penagih dadah dikalangan remaja. Merujuk petikan dalam rencana (Berita Sinar Harian, 2021), laporan berita yang dikeluarkan oleh Pertubuhan Bangsa-Bangsa Bersatu mendapati pasaran dadah global semakin meningkat di mana terdapat peningkatan penyeludupan yang mendadak di kawasan 'Segi Tiga Emas' yang melibatkan negara jiran Thailand, Myanmar dan Malaysia di mana dengan peningkatan secara mendadak yang ditunjukkan oleh pengeluaran syabu, opiat dan kokain. Bagi aspek umur pula, laporan tersebut menyatakan umur 12 sehingga 17 tahun adalah umur yang berisiko tinggi bagi penglibatan dengan penyalahgunaan dadah.

\section{Penyataan Masalah}

Menurut petikan dalam rencana (Berita Sinar Harian, 2020), satu faktor yang paling relevan mempengaruhi peningkatan penyalahgunaan bahan ialah umur yang mula mengambil dadah iaitu seawal usia kanak-kanak ke peringkat remaja. Jika seseorang mengambil dadah pada peringkat umur yang sangat muda, risiko penglibatannya dalam penagihan adalah tinggi. Melalui dasar dadah negara, matlamat kerajaan Malaysia untuk melihat negara Malaysia bebas dadah pada tahun 2015 tidak berjaya, namun yang demikian untuk mencapai matlamat negara maju kita tidak boleh biarkan negara kita ditunggangi oleh masalah dadah yang membelenggu masyarakat tidak terkecuali impaknya kepada golongan remaja. Kadar penyalahgunaan dadah tidak berkurang malah semakin meningkat dari semasa ke semasa. Golongan di kalangan remaja juga tidak terkecuali menyumbang kepada statistik peningkatan penyalahgunaan dadah di Malaysia. Impak kepada celik akal yang betul dan sahih mengenai penyalahgunaan dadah merupakan satu langkah yang dilihat bertepatan bagi berhadapan 
dengan penyalahgunaan dadah. Apabila memperkatakan tentang penyalahgunaan dadah, maklumat yang betul merupakan satu perkara yang penting bagi menjana perubahan tingkah laku dalam kalangan remaja (Ku Suhaila, 2017). Walau bagaimanapun, berdasarkan senario pada hari ini, penyebab yang sering kali dikaitkan dengan trend kehidupan modenisasi adalah implikasi gaya hidup yang diamalkan masa kini. Kajian oleh Amadi dan Akpelu (2018), yang menggunakan pendekatan epidemiologi mendapati jika langkah pencegahan yang efektif tidak diambil di peringkat awal, maka ianya akan menjadi masalah sosial dan kesihatan yang cukup serius melangkaui kesejagatan dunia pada masa hadapan.

Pengaruh celik akal adalah elemen yang penting dan tidak boleh diabaikan begitu sahaja serta dipandang sebelah mata kerana ianya boleh memberi tanggapan yang salah serta gagal untuk memberikan impak pencegahan dadah dalam erti kata yang sebenarnya. Oleh itu, kesan bagi kajian yang dilakukan adalah bagi melihat impak dari penggunaan atau penyalahgunaan dadah oleh penagih remaja dari pelbagai konteks iaitu diri sendiri, keluarga, masyarakat dan negara. Ianya juga bertujuan mengenal pasti kesan positif atau negatif akibat perlakuan sikap atau tingkah laku penggunaan bahan tersebut satu gambaran am serta skop yang menerangkan latar belakang kajian, permasalahan kajian dan hala tuju topik. Selain daripada itu, ia juga menerangkan kepentingan kajian untuk menangani isu penyalahgunaan dadah khususnya dalam kalangan remaja bagi penghasilan modul pendidikan pencegahan yang efisien serta efektif oleh Agensi Antidadah Kebangsaan Malaysia.

\section{Sorotan Literatur}

Merujuk kepada kajian-kajian yang lepas hasil dari carian mendapati tidak banyak kajian-kajian yang lepas mengenai kurang 'celik akal' tentang dadah ditemui di mana hanya terdapat beberapa contoh kajian lepas yang agak lama yang dijumpai yang menyatakan tentang 'celik akal' adalah merupakan wadah kombinasi pelbagai informasi yang mempunyai pemahaman dan potensi sesuatu perkara serta isu, namun tidak banyak pengetahuan yang membawa kepada celik akal berlaku apabila seseorang itu percaya maklumat itu adalah betul dan salah di mana faktor ini juga dapat mengimbangi kecerdasan celik akal yang mengemudi kepada kewarasan mental seseorang (O’Brien, 2006). Pelajar yang berusia 13 sehingga 18 tahun serta pernah terlibat dengan penyalahgunaan dadah melihat kesan negatif yang lebih teruk berbanding dengan pelajar yang tidak pernah terlibat. Ini adalah kerana mereka yang terlibat dengan penyalahgunaan dadah ini akan berhadapan dengan kesannya secara langsung tanpa ada batasan dan rintangan (Nurul Shafini, 2018). Program pencegahan yang berasaskan pendidikan berfokus kepada golongan sasar juga dapat mengurangkan risiko dan meningkatkan faktor perlindungan daripada faktor berisiko yang berkaitan dengan bahan terlarang yang lain (Noordeyana et al., 2018). Kurang celik akal terhadap dadah turut menjadi faktor penyumbang kepada berlakunya penyalahgunaan dadah dan menyatakan sebenarnya bahawa remaja-remaja di negara kita tidak mempunyai pengetahuan yang mendalam tentang kesan negatif serta bahaya penyalahgunaan dan penggunaan dadah (Noorazleen, 2015).

Dapatan yang menarik di dalam kajiannya terhadap pelajar perubatan di India mengenai Celik akal (pengetahuan atau kesedaran) berkaitan penagihan dadah, di mana beliau mendapati kebanyakan pelajar mempunyai asas mengenai dadah. Pengetahuan yang dimiliki oleh mereka turut merangkumi kesan tahap psikologikal serta fizikal bagi setiap dadah. Namun demikian, mereka juga didapati tidak mempunyai pengetahuan yang tepat serta sahih mengenai hukuman serta perundangan berkaitan dengan penyalahgunaan dadah. Malahan, mereka juga tidak mengetahui peranan yang perlu dilakukan bagi menghadapi pesakit yang mengalami simptom penyalahgunaan dadah. Kajian ini juga menyatakan pelajar perubatan mempunyai pengetahuan yang cukup terhad mengenai punca penagihan dadah serta perkara klinikal yang berkaitan penyalahgunaan dadah keseluruhannya. (Rathore, Joshi \& Pareek, 2017). 


\section{Metod Kajian}

Kaedah kajian yang digunakan untuk meneroka 'kurang celik akal' terhadap dadah dan kesan dalam penagih remaja di Pusat Pemulihan Sukarelawan Dadah di bawah pemantauan AADK. Suatu kajian dijalankan oleh pengkaji disebabkan mempunyai keinginan yang kuat untuk mengetahui secara mendalam sesuatu fakta, pengalaman, data-data tertentu, konsep, inferens, andaian dan pelbagai lagi. Reka bentuk kajian ialah pelan tindakan yang memperlihatkan secara terperinci bagaimana sesuatu kajian itu dijalankan (Creswell, 2014). Kajian ini pada secara umumnya menggunakan pendekatan kualitatif. Kaedah pendekatan kualitatif menggunakan temu bual semi struktur untuk mendapatkan maklumat tentang hubungan yang boleh membawa kepada pembentukan konsep terhadap fenomena yang dikaji. Pengkaji menggunakan kajian pendekatan kualitatif untuk meneroka tahap 'celik akal' terhadap dadah dan kesan yang diketahui oleh penagih remaja berdasarkan beberapa faktor yang bersesuaian bagi menerokai dengan lebih terperinci mengenai tahap 'celik akal' terhadap pengetahuan dadah. Pendekatan kualitatif menekankan penerokaan yang mendalam dan kefahaman peserta kajian berdasarkan perspektif pengetahuan konstruktivis serta transformatif

Dalam kajian ini, berdasarkan Creswell (2014), yang menyatakan 6 hingga 7 orang subjek yang menjadi sampel kajian dalam penyelidikan kualitatif sudah mencukupi untuk menjalankan penyelidikan secara holistik, maka pengkaji telah menetapkan seramai 6 subjek yang terdiri daripada penagih remaja serta dipilih rawak berdasarkan umur di antara 13 sehingga 18 tahun. Mereka juga telah mengambil dadah bagi tempoh yang minima di antara enam bulan sehingga setahun dan datang secara sukarela. Persampelan rawak dipilih kerana setiap individu dalam kajian ini berpeluang mempunyai kebarangkalian yang sama untuk terpilih atau dijadikan sebagai subjek kajian. Subjek kajian atau peserta yang dipilih secara rawak dapat meningkatkan kemungkinan bahawa subjek akan mewakili secara tepat populasi kajian dan ini membolehkan persoalan kajian dapat diterima kesahihannya.

Teknik temu bual digunakan oleh pengkaji kerana merupakan satu kaedah yang pantas bagi memperoleh banyak maklumat dalam satu masa yang singkat (Merriam, 2009). Kaedah ini membantu pengkaji untuk menyelami pengalaman, pemikiran dan penjelasan lanjut oleh peserta kajian. Temu bual menggunakan soalan semi struktur yang mengandungi empat bahagian terdiri daripada Bahagian A: Demografi, Bahagian B: Pengetahuan Dadah, Bahagian C: Kesan Penyalahgunaan Dadah, Bahagian D: Sumber Maklumat Pengetahuan Dadah. Berikut adalah merupakan contoh soalan bagi mencapai persoalan kajian yang dikehendaki.

kajian ini adalah kajian kualitatif dengan menggunakan kaedah kajian kes. Pemilihan dan jumlah responden bergantung kepada titik ketepuan semasa tema/sub tema setiap aspek timbul. Prosedur pengumpulan data dan analisis data dipatuhi bagi memastikan dapatan kajian adalah sah dan tepat. Perbincangan kesahan, kebolehpercayaan dan etika turut terangkum dalam bab ini. Tema dan sub tema dibincangkan dengan teliti serta secara konsensus agar memberi makna yang mempunyai pengertian tersendiri kepada kajian ini dan seterusnya dapat memberi impak kepada pihak berkepentingan di negara ini dalam isu yang dikaji.

\section{Hasil Kajian}

Dapatan kajian berkaitan dengan hasil laporan kajian berdasarkan data-data yang diperoleh melalui kaedah pengumpulan data penyelidikan secara kualitatif. Data-data yang diperolehi dikategorikan mengikut tema dan merupakan intipati penting dalam kajian bagi memudahkan pengkaji memahami serta menganalisis data secara terperinci. Dapatan ini meneroka serta menelusuri tahap celik akal tentang dadah dan kesan dalam kalangan penagih remaja iaitu bilangan peserta dalam kekerapan bagi perkataan di dalam tema yang ditetapkan.

Seramai 6 orang responden telah dipilih setelah memenuhi kriteria yang diperlukan bagi kajian ini. Kesemua mereka adalah lelaki dan berusia di antara 16 sehingga 18 tahun. Pembabitan mereka di dalam kancah penagihan pula adalah selama 6 bulan sehingga 1 tahun. Mereka juga telah dirujuk secara sukarela oleh keluarga terdekat iaitu ibu bapa, abang, kakak dan nenek. Ianya juga adalah program 
rawatan pemulihan yang julung kali diikuti oleh mereka setelah bergelumang di dalam dunia penagihan dadah selama ini. Jika ditinjau dari demografi, didapati kesemua peserta adalah berbangsa Melayu. Dari aspek agama mereka adalah beragama Islam. Seramai dua orang mendapat pendidikan sehingga Sijil Pelajaran Malaysia (SPM), dua orang memperoleh pendidikan sijil Pentaksiran Tingkatan Tiga (PT3) dan dua orang lagi hanya menamatkan pendidikan di tingkatan 2 sahaja. Hanya dua orang yang bekerja iaitu sebagai pekerja kilang, manakala empat orang lagi adalah penganggur. Dapatan kajian berdasarkan temu bual yang dijalankan dalam kalangan penagih remaja sehingga menemui titik tepu dan ayat serta perkataan yang menjadi persamaan serta diulangi sehingga tepu oleh peserta-peserta berkenaan dikodkan sebagai tema.

Merujuk kepada tema hasil dapatan analisis soalan 1, adalah bagi mengetahui sejauh manakah tahap celik akal terhadap peserta-peserta yang terlibat, merujuk kepada tema utama yang terhasil daripada penerokaan mengenai pengetahuan umum mengenai dadah iaitu bahan bahaya. Seramai empat orang peserta $(67 \%)$ dari enam orang peserta yang ditemu bual menyatakan dadah ini adalah bahan yang bahaya. Dua orang lagi peserta (33\%) menyatakan dadah ini boleh menjadikan mereka rajin bekerja.

Bagi peserta 1 (lelaki, umur 16) ada menyentuh mengenai baik dan buruk dadah dari perspektif beliau sebagai pengguna:

"Bila dapat hisap barang ni semua rasa jadi pandai... kipas rosak ..kita boleh repair..Emmm barang ni bahaya jugak la..dah lama ambik barang ni.. susah nak tinggal.. saya rasa best sangat bila dapat barang ni...tak dapat badan lemah...itu yang saya tau la..." (1 Jun 2021/TB:18-20)

Penekanan mengenai dadah adalah bahan bahaya ini turut dijelaskan dan dinyatakan oleh peserta 2 (lelaki, umur 18):

“...oooo macam..barang niii... rasanya..boleh merosakkan badan ....bahaya..itulah saya faham, lain pada tu saya tak tau la pula”. (2 Jun 2021/TB: 19-20)

Peserta 4 (lelaki, umur 18) menegaskan secara ringkas dan mudah bagi beliau adalah pelabelan:

"Dadah ka.. eemm..bahaya...sejenis syabu..." (4 Jun 2021/TB : 14])

Peserta 6 (lelaki, umur 17) senada dengan tiga peserta sebelum ini tetapi sesuatu menarik untuk dikongsi iaitu faktor turut ingin mengetahui bahaya bahan tersebut, adalah penyumbang kepada penagihan beliau:

“...tak la saya tau sangat, tapi benda bahaya macam ni...kan, selalu tengok juga dalam tv, tu la yang saya nak cuba dan ikut kawan kerana nak tau bahaya dadah itu sendiri..."(6 Jun 2021/TB : 17-19)

Berdasarkan analisis dapatan soalan 1, menunjukkan peserta mengetahui secara umum mengenai dadah iaitu sejenis bahan bahaya sahaja tanpa dapat memperincikannya secara mendalam iaitu empat orang peserta $(66 \%)$ dan yang paling mengejutkan terdapat dua orang peserta pula $(33 \%)$ menyatakan dadah sebagai bahan untuk membantu mereka kuat bekerja.

Merujuk dapatan analisis soalan 2, didapati peserta kajian mempunyai pengetahuan mengenai jenis dadah berdasarkan kegunaan semasa dalam penagihan. Justeru itu, terdapat peserta yang boleh menyatakan tiga atau empat jenis dadah kerana mereka pernah mengambilnya sebelum ini. Nama jalanan bagi dadah yang sama seperti syabu iaitu kristal turut disebut di dalam temu bual ini. Tema utama yang diwujudkan daripada temu bual berkaitan pengetahuan mengenai jenis dadah adalah syabu kerana dadah ini yang digunakan oleh semua enam peserta kajian (100\%) yang terlibat dalam penagihan.

Pandangan oleh peserta 1 (lelaki, umur 16): 
Asian Social Work Journal (ASWJ), Volume 6, Issue 5, (page 42 - 55), 2021

DOI: https://doi.org/10.47405/aswj.v6i5.187

“Syabu,pil kuda, pil goyang itu ja, yang lain saya tak tau” (1 Jun 2021/TB: 22])

Peserta 2 (lelaki, umur 18) menyatakan secara ringkas:

“Kristal...syabu...yang lain saya tak tau la pulak...(2 Jun 2021/TB:22)

Bagi peserta 3 (lelaki, umur 18) pandangannya pula adalah seperti berikut:

"Tak juga banyak yang saya tau...macam ganja, ectascy, syabu, pil-pil tu ja la yang saya tau..." (3 Jun 2021/TB: 20-21)

Peserta 4 (lelaki, umur 18) pula menjelaskan mengikut apa yang digunakan oleh beliau sendiri:

"Jenis yang saya gunalah ...macam syabu,heroin, kokain, ecstacy..itu saja..” (4 Jun 2021/TB: 16-17)

Peserta 5 (lelaki, umur 18) menyatakannya yang diketahuinya sahaja:

"Jenis dadah ya...maksudnya saya guna ya ..methamphetamine, syabu, ectasy...errr morfin yang itu je yang saya tau lah..” (5 Jun 2021/TB: 18-19)

Pernyataan berkaitan jenis dadah yang sama turut seiringan dengan kenyataan oleh peserta 6 (lelaki, umur 17) iaitu:

"Emmmm..macam saya ambil macam syabu, ganja, kokain yang saya tau, kerana saya pernah amik dan try ..." (6 Jun 2021/TB: 21-22)

Analisis dapatan soalan 2 memperlihatkan semua peserta kajian (100\%) mengetahui jenis dadah hanya berdasarkan penggunaan oleh mereka sendiri semasa berada dalam kancah penagihan dan tidak mengetahui mengenai jenis dadah yang lain kerana mereka tidak menggunakannya bagi tujuan penagihan.

Hasil dapatan analisis soalan 3 , tema yang terhasil dari perincian temu bual adalah pengambilan dos berlebihan. Seramai tiga orang peserta $(50 \%)$ menyatakan penyalahgunaan dadah adalah pengambilan dos berlebihan, seorang menyatakan bahan merosakkan, seorang lagi pula mengatakan mencuba dan yang terakhir mengatakan tidak tahu.

Pengambilan dos berlebihan seperti dinyatakan oleh peserta 3 (lelaki,umur 18):

"Emmm....macam penggunaan dadah berlebihan tu, macam ubat hospital kalau dos kecil sahaja tapi kalau dos banyak ... dia orang cakap boleh jadi syabu...syabu dos kecil tidak bahaya jugak tu..guna sikit-sikit ja boleh la...." (3 Jun 2021/TB: 2325)

Kenyataan ini turut mempunyai persamaan dengan apa yang diperihalkan oleh peserta 5 (lelaki, umur 18):

"Penyalahgunaan dadah ya..maksudnya ...emmm..macam mengambil dos berlebihan kan.. lebih kurang macam tu la.." (5 Jun 2021/TB: 21-22)

Ianya turut senada dengan peserta 6 ( lelaki, umur 17):

"Macam mana mau jelaskan.....macam ubat kita guna sedikit ok..kalu banyak dos...banyak masalah ....lebih kurang macam tu la ...” (06 Jun 2021/TB: 24-25)

Analisis dapatan soalan 3 menunjukkan tiga peserta (50\%) telah mengatakan bahawa penyalahgunaan dadah sebagai pengambilan dos berlebihan seumpama melebihi pengambilan ubat yang dibenarkan di 
DOI: https://doi.org/10.47405/aswj.v6i5.187

hospital dan kefahaman ini telah disalah ertikan sebagai menghalalkan matlamat mereka mengambil dadah jika ianya di dalam dos yang kecil.

Bagi dapatan analisis soalan 4 pula, tema yang terbentuk dari penelitian mendalam pengetahuan mengenai penagihan dadah adalah gian. Seramai empat orang peserta atau (67\%) telah menyatakan perkataan gian iaitu keinginan atau kerinduan yang melampau terhadap dadah, dimana pengulangan pengambilan bahan perlu dilakukan berkali-kali bagi menghilangkan gian tersebut. Dua orang peserta pula hanya mengulangi perkataan ketagih apabila diajukan persoalan ini.

Peserta 2 (lelaki, umur 18) menyatakan penagihan adalah seperti berikut:

"Sama macam gian la, kalau nak buang barang tu dari badan susah laa." (2 Jun 2021/TB: 26-27)

Pandangan dari peserta 3 (lelaki, umur 18) cukup menarik:

"Macam kalau sudah sekali kita guna,pastu akan jadi berlarutan..mau berkali-kali lagi ..rasa macam gian laaa.....for fun, kadang untuk hilangkan stress......tidak boleh berhenti macam tu je....." (3 Jun 2021/TB: 27-29)

Peserta 4 (lelaki, umur 18) juga sependapat dengan peserta lain:

"Macam...pengambilan syabu..gian mau layan mau ambil selalu.."(4 Jun 2021/TB: 19)

Ini juga senada dengan pandangan peserta 6 (lelaki, umur 17):

“ macam gianlah...yang macam tu la... susah nak habaq ...macam mau hari-hari ..ooo" (6 Jun 2021/TB: 26-28])

Dapatan analisis soalan 4, ini merungkai pengetahuan sebenar penagihan dadah oleh penagih itu sendiri iaitu berkisar dalam perkataan gian seramai empat orang $(67 \%)$ dan ini menjelaskan pengalaman mereka sendiri untuk menyatakan pengetahuan yang diketahui selama ini.

Dapatan Analisis Soalan 5, tema yang terhasil dari penerokaan pengetahuan mengenai ciri-ciri penagih dadah iaitu ciri-ciri fizikal seperti mata merah,pipi cengkung dan psikologikal seperti tidak boleh tidur, pemikiran tidak waras serta tingkah laku yang tidak boleh dijangkakan, namun demikian, terdapat seorang peserta kajian yang menyatakan ciri seorang penagih dadah merupakan individu yang rajin bekerja. Semua enam peserta atau mengikut peratusannya (100\%) menyatakan ciri-ciri tersebut berdasarkan apa yang berlaku kepada diri mereka.

Kenyataan oleh peserta 1 (lelaki, umur 16), diperihalkannya seperti berikut:

“Mata kuning, tak makan, pipi cekung, tak tiduq ... tu jea." (1 Jun 2021/TB: 34)

Peserta 2 (lelaki, umur 18) menyatakan seiring dengan peserta lain,namun menyentuh ciri kognitif;

"Mata berkaca-kaca, muka kesung, rajin buat kerja...tak boleh tiduq.." (02 Jun 2021)

Pendapat peserta 3 (lelaki, umur 18) pula seperti berikut:

“...tidak terurus, pekerjaan terganggu..tidak fokus...mata merah..dulu gemuk sekarang kurus..” (3 Jun 2021/TB: 31-33)

Peserta 4 (lelaki, umur 18) mengatakan dari aspek yang merangkumi dua ciri iaitu fizikal serta psikologi: 
DOI: https://doi.org/10.47405/aswj.v6i5.187

Ciri-ciri ni macam pencuri, mata merah, kuat marah..apa tu..tidak tahu hala tuju ..macam gaya apa tu ..susah nak bagitau ..macam tak betul saja pemikiran tu.." (4 Jun 2021/TB: 23-25)

Peserta 5 ( lelaki, umur 18) pula menyatakan secara ringkas seperti berikut:

"Ciri-ciri ya macam mana ya....mau fikir....kurus macam saya ...macam dia hyperaktif kot....ya macam tu la....." (6 Jun 2021/TB: 30-33)

Pandangan peserta 6 (lelaki, umur 17) pula agak menyeluruh:

"Ciri-ciri yang mengambillah ...kurang selera makan...mata berkaca-kaca ..macam berair. Selepas 2 atau 3 hari ambil barang.....kita jadi kuat marah....panas baran, pemikiran macam tidak waras dah .......emmm...tingkah laku jenis tidak fikir panjang...terus ambil tindakan gitu ja ...” (6 Jun 2021)

Hasil dapatan analisis soalan 5, menjelaskan semua enam peserta (100\%) berupaya menghuraikan ciriciri penagih dadah yang berasaskan apa yang dialami sendiri oleh mereka semasa berada dalam dunia penagihan dadah sebelum ini.

Dapatan analisis soalan 6, tema utama yang dihasilkan dari intipati temu bual berkaitan dengan cadangan mengatasi masalah penyalahgunaan dadah dalam kalangan remaja iaitu mendekati keluarga. Dua orang peserta (33\%) menyatakan keluarga merupakan mekanisme atau instrumen yang penting bagi mengatasi masalah penyalahgunaan dadah dalam kalangan remaja. Pandangan peserta yang lain pula adalah mengisi masa lapang dengan perkara yang berfaedah dan bermanfaat, manakala seorang mengatakan bahawa perlu bijak mengawal nafsu apabila berada di dalam komuniti. Penelitian prognosis keperibadian diri sebagai uslub memilih kawan secara bijak juga ditekankan oleh seorang peserta dan yang terakhir merupakan nasihat peserta berdasarkan pengalaman beliau serta situasi yang dihadapinya dengan menyarankan untuk mendapatkan rawatan lebih awal jika terjerumus dalam penagihan dadah.

Pendapat peserta 1 (lelaki, umur 16):

"Rapat dengan keluarga ...emmm..pergi mana -mana pun dengan keluarga, ya keluarga yang penting .." (1 Jun 2021 /TB: 37-38]

Pandangan beliau turut mempunyai persamaan dengan peserta 2 (lelaki, umur 18):

"Rapat dengan family...dan kaunseling ..nampak boleh membantu masalah dadah ini." (2 Jun 2021/TB : 36-37)

Dapatan analisis soalan 6, mengutarakan cadangan atau syor untuk mengatasi masalah penyalahgunaan dadah dalam kalangan remaja daripada perspektif penagih itu sendiri. Dua orang peserta kajian ini (33\%) menyarankan bahawa indikator keluarga adalah elemen pencegahan yang ampuh bagi menangani isu berkenaan.

Dapatan analisis soalan 7, tema yang terbentuk adalah tindak balas badan terhadap dadah jenis syabu kerana enam orang peserta kajian $(100 \%)$ terdiri daripada mereka yang mempunyai sejarah serta pengalaman dengan penagihan dadah jenis syabu. Namun demikian, terdapat seorang peserta telah menyatakan kesan dari tiga jenis dadah terhadap tubuh badan iaitu syabu, ganja dan kokain. Peserta memerihalkan kesan dadah tersebut berdasarkan ciri- ciri fizikal dan psikologikal serta simptom yang dialami oleh mereka sendiri.

Peserta 1 (lelaki, umur 16) menyatakannya seperti berikut: 
DOI: https://doi.org/10.47405/aswj.v6i5.187

"Macam syabu...mula-mula bagi semangat tapi lama-lama jadi lemah terus...susah mau cakap la bila dah kena barang ni..tak bole tidur..bole berjaga..otak rasa macam bagus ja.." (1 Jun 2021/TB : 41-43]

Ini senada dengan penyataan peserta 2 (lelaki, umur 18):

"Syabu...mulanya untuk rajin bekerja...lama-lama sudah biasa kalau takda syabu ...tak boleh bekerja....badan sakit-sakit ..sakit semua .."

(02 Jun 2021/TB: 40-41)

Manakala peserta 3 (lelaki, umur 18) menyingkap dari aspek kawalan pemikiran:

“...Jenis syabu..effect dia..ada kesan..badan jadi kuat..tidak mengantuk tuu ...boleh berjaga satu minggu ooo..." (3 Jun 2021/TB : 41-42)

Bagi peserta 4 (lelaki, umur 18) pandangannya adalah seperti berikut:

"Kalu syabulah..kurus..panas baran...tiba-tiba stress..tak cukup tidur...” (4 Jun 2021/TB: 32-33)

Peserta 5 (lelaki, umur 18) menegaskan:

“...ya macam saya, guna syabu...buat fikiran tidak waras...hilang selera makan ... rasa macam mau gila..kesan dia,.. rasa tak tenteram dalam hidup..." (5 Jun 2021/TB: 34-36)

Peserta 6 ( lelaki, umur 17) pula berpandangan seperti berikut:

"Macam syabu, kesan tubuh badan macam kuruslah,susut badan ..lepas tu..err. bawah mata ada hitam.. "Ganja pula kesan dia ...lepas ambil..mau makan..macam pemikiran kita set rasa untuk makan saja...kalau pemikiran rasa macam mau mati...badan pun sama rasa macam mau mati jugak...satu lagi kokain...macam bagi enjoy kepada badan....macam untuk menari...lepas khayal dan menari....kesan macam syabu jugak tapi tak la teruk macam syabu... (6 Jun 2021/TB : 40-45)

Berdasarkan dapatan analisis soalan 7, semua enam orang peserta (100\%) mempunyai persamaan pengetahuan dari sudut jenis dadah iaitu syabu terhadap tubuh badan kerana telah mengalaminya apabila mengambil bahan tersebut sehingga mengalami ketagihan. Hanya seorang sahaja menjelaskan dua lagi jenis dadah iaitu ganja dan kokain terhadap tubuh badan apabila bahan tersebut digunakan.

Dapatan Analisis Soalan 8, menjelaskan tema yang terhasil dari penerokaan mengenai maklumat kesan penyalahgunaan dadah kepada kehidupan individu adalah gagal untuk menguruskan kehidupan seharian. tiga orang peserta $(50 \%)$ menyatakan kehidupan individu berkenaan tidak terurus, dua orang peserta $(33 \%)$ pula mengatakan tingkah laku mereka menjadi agresif dan seorang peserta menyatakan kesan yang baik iaitu dapat bergembira.

Kehidupan tidak terurus ini telah diperihalkan oleh peserta 3 (lelaki, umur 18):

“jadi tak teratuq tu dah...selalu jadi mengelabah ja ... (3 Jun 2021/TB: 45-46]

Ini juga seiring dengan pernyataan oleh peserta 4 (lelaki, umur18) iaitu:

"adoii...macam tidak terurus dah, selalu rasa macam ada masalah ...stres.." (4

Jun 2021/TB: 36-37] 
DOI: https://doi.org/10.47405/aswj.v6i5.187

Perihal yang sama turut dinyatakan oleh peserta 5 (lelaki, umur 18):

"Kehidupan tak terurus...tak macam orang lain....semua huru-hara laa, serabut...." (5 Jun 2021/TB : 38-41)

Bagi tingkah laku agresif peserta 2 (lelaki, umur 18) menyatakan seperti berikut:

"Kuat melawan semua orang...tak fikir pasal orang lain dah...kita sahaja yang betul..orang lain semua salah.... apa yang kita buat kita rasa seronok ...kita tak mau tau apa orang lain kata ....janji seronok....boleh bekerja..” (2 Jun 2021/TB: 44-46]

Berdasarkan dapatan analisis soalan 8, tiga orang peserta (50\%) menyatakan kehidupan tidak terurus, dua orang peserta (33\%) pula mengatakan tingkah laku individu menjadi agresif implikasi impak penyalahgunaan dadah kepada kehidupan seseorang tersebut. Tetapi yang harus diberikan perhatian serius adalah pernyataan oleh seorang peserta iaitu kesan positif kegembiraan kepada diri individu apabila menyalahgunakan bahan tersebut.

Dapatan analisis soalan 9, tema yang terhasil dari temu bual yang terperinci adalah keharmonian keluarga terjejas. Empat orang peserta (67\%) menyatakan ahli keluarga selalu bergaduh di antara satu sama lain dan keharmonian keluarga terjejas. Dua orang peserta (33\%) pula menegaskan ianya membawa kemudaratan serta menyukarkan kehidupan semua ahli keluarga.

Peserta 1 (lelaki, umur 16) dalam aspek yang inklusif:

"Melawan ibubapa..macam selalu gaduh-gaduh..marah-marah..tak sebelum ini..kita jadi berani lawan mak dengan bapa...pasal barang tu la...” (1Mac 2021/TB: 53-54]

Peserta 2 (lelaki, umur 18) pula menyatakannya dalam situasi seperti berikut: “ Huru-hara la...macam-macam jadi... ibubapa selalu bergaduh....last bercerai..kakak selalu stress tengok saya ...semua kucar-kacir....bukan macam keluarga orang lain...semua orang susah hati, rasa sedih ja...." (2 Jun 2021/TB: 48-51]

Ulasan peserta 5 (lelaki, umur 18) pula sebagaimana berikut:

"Keluarga jadi ...kucar kacir..tak ada persefahaman..dan selalu bergaduh..selalu berselisih faham ..ibubapa marah-marah saja...adik beradik marah ..gaduhgaduh..tak macam dulu lagi.." (5 Jun 2021/TB: 45-47]

Pemerihalan perkara tersebut secara konstruktif oleh peserta 6 (lelaki, umur 17):

"Menyusahkan dia orang..macam menghabiskan wang ke sana ke sini.......adik beradik selalu bergaduh dan tak ngam selalu...macam-macam lah...Hubungan adik beradik selalu tegang, bergaduh ...memang tak ngam dah..." (6 Jun 2021/TB:57-60)

Berdasarkan dapatan analisis soalan 9, empat orang peserta (67\%) menyatakan keluarga tidak harmoni, dua orang peserta (33\%) pula memaklumkan kesan penyalahgunaan dadah turut memberi kemudaratan kepada ahli keluarga yang lain meskipun mereka tidak terlibat secara langsung dengan gejala penagihan bahan tersebut.

Dapatan analisis soalan 10 pula, tema yang terbentuk dari penerokaan mengenai maklumat kesan penyalahgunaan dadah terhadap masyarakat dan negara ialah wujudnya ancaman kepada komuniti serta menyebabkan kemusnahan kepada negara. Enam orang peserta $(100 \%)$ mengatakan ketenteraman 
DOI: https://doi.org/10.47405/aswj.v6i5.187

masyarakat terancam dan negara mengalami kehancuran apabila berlakunya gejala penagihan dadah secara berleluasa.

Pandangan oleh peserta 1 (lelaki, umur 16) pula menyatakan terdapat persepsi tidak selamat dalam masyarakat apabila berlakunya kegiatan penyalahgunaan dadah:

\begin{abstract}
"Orang kampung macam tengok lain...kami pun tak takut pasal ada barang tu.... masyarakat macam takut tengok kami...kami tak curi apa-apa dari mereka ..” (1 Jun 2021/TB: 57-59]
\end{abstract}

Peserta 2 (lelaki, umur 18) mengulas dari aspek stigma komuniti seperti berikut:

"Masyarakat pandang buruk kepada kami satu keluarga...sentiasa cerita buruk tentang diri saya dan keluarga..kerana barang tu...boleh hancurkan negara ....” (2 Jun 2021/TB: 54-56]

Penyataan peserta 3 (lelaki, umur 18) menekankan terhakisnya ikatan serta jalinan ukhuwah di dalam komuniti yang dizahirkannya seperti berikut:

"Kesan masyarakat ada..tidak ada kerjasama dalam masyarakat bila ada dadah....macam pecah belah dalam masyarakat..mereka lihat macam lain kalau ada penagih ..dan negara boleh hancur.." (3 Jun 2021/TB: 54-55]

Kenyataan peserta 4 (lelaki, umur 18) memperlihatkan tanggapan masyarakat dan kesannya terhadap negara pada mata beliau:

“Kesan masyarakat macam tak percaya kepada kita sudah... kita macam
sampah..itulah..mereka tengok macam ...susah nak jelaskan la...tapi tak
eloklah...macam ni negara boleh musnah kalau ramai yang terlibat dengan
dadah..” (4 Jun 2021/TB: 46-48]

Ulasan oleh peserta 5 (lelaki, umur 18) agak menarik perhatian untuk situasi sebenar dalam masyarakat dan negara iaitu:

“Macam mana ya..masyarakat kan.....dah pandang serong pada kita ja..macam
kita ni buruk saja ..tak berguna bagi mereka...negara musnah kerana orang
macam kita ni, rasa lemah..mau urus diri susah .. negara pun tak mau lagi orang
macam kami..” (05 Jun 202/TB: 48 - 53]

Bagi peserta 6 (lelaki, umur 17), timbulnya prasangka serta persepsi tidak selamat dalam kalangan masyarakat kerana adanya ancaman penagihan dadah seperti dinyatakan oleh beliau:

"Orang pandang hina ...macam mana mau jelaskan ya..Diorang tau saya ambil barang..kalau saya lalu depan mereka, mereka tengok macam mau makan orang saja...negara pun musnah klau sudah banyak penagih dadah .." (6 Jun 2021/TB : 63-65]

Berdasarkan dapatan analisis soalan 10, semua enam orang peserta kajian atau (100\%) menyatakan ketenteraman masyarakat terancam serta tergugat dan boleh mendatangkan kehancuran negara jika gejala penagihan masih berterusan tanpa sebarang langkah yang diambil bagi menanganinya secara efisien pada masa hadapan.

Dapatan Analisis Soalan 11, tema yang terhasil dari perincian temu bual berkaitan sumber memperolehi maklumat mengenai pengetahuan dadah dan kesannya adalah kawan. Semua enam orang peserta $(100 \%)$ menyatakan kawan adalah sumber utama untuk memperolehi maklumat atau informasi 
DOI: https://doi.org/10.47405/aswj.v6i5.187

mengenai pengetahuan dadah. Hanya seorang peserta yang turut memaklumkan maklumat juga diperolehi daripada Agensi Antidadah Kebangsaan Malaysia.

Bagi sumber melalui kawan, ini telah dijelaskan oleh penyataan peserta 1 (lelaki, umur 16) seperti berikut:

"Kawan-kawan yang bagitau... semua yang bagus-bagus saja ...tak cerita pun yang bahaya... macam tau dadah bahaya..tapi mau tau bahaya dia macam mana tu... ..." (1 Jun 2021/TB: 64-65]

Peserta 2 (lelaki, umur 18) memberikan gambaran yang relevan dengan senario semasa:

"kawan-kawanlah yang selalu bagitau kristal ka, syabu ka...semua yang baik saja..untuk kuatkan kerja. (2 Jun 2021/TB: 62-65]

Bagi peserta 3 (lelaki, umur 18) cukup ringkas dan padat ayatnya:

“Dari kawan-kawan sahaja dan pergaulan..tiada yang lain.." (3 Jun 2021TB: 59]

Untuk peserta 4 (lelaki, umur 18) menegaskan seperti berikut:

“Dari kawan-kawan....kawan-kawan yang ajar.." (4 Jun 2021/TB: 51]

Peserta 5 (lelaki, umur 18) memaklumkan AADK juga merupakan sumber maklumat pengetahuan dadah seperti kenyataan berikut:

“Dari ...AADK yang dapat saya tau....” (5 Jun 2021/TB: 56]

Pendapat oleh peserta 6 (lelaki, umur 17) pula menegaskan kawan sebagai saluran utama bagi mendapatkan maklumat dadah di samping bertindak sebagai perangsang semangat di dalam pembabitan dunia jenayah:

"Saya tau dari kawanlah..kawan yang mengesyorkan. Kawan kata ada 3 cara untuk kaya cepat ...pelacuran ...judi dan dadah..." (6 Jun 2021/TB: 57-59]

Berdasarkan dapatan analisis soalan 11, semua enam orang peserta kajian (100\%) jelas menjadikan kawan sebagai rujukan utama bagi memperolehi maklumat pengetahuan dadah yang ingin diketahui oleh mereka selama ini, di samping seorang peserta turut menyatakan Agensi Antidadah Kebangsaan Malaysia sebagai salah satu sumber perolehan maklumat berkenaan.

Bagi dapatan analisis soalan 12 yang akhir di mana tema yang terbentuk dari penerokaan cadangan sistem penyaluran maklumat pengetahuan dadah dan kesannya bagi memastikan remaja tidak terlibat dengan penyalahgunaan dadah adalah kempen antidadah yang agresif. Lima orang peserta (83\%) jelas memberitahu bahawa memperhebatkan kempen adalah mekanisme yang tepat untuk menyalurkan informasi yang betul kepada masyarakat khususnya remaja. Seorang peserta pula yang mencatatkan peratusan $(17 \%)$ pula menyatakan bahawa pihak kerajaan sendiri yang perlu memikirkan cadangan tersebut.

Peserta 2 (lelaki, umur 18) menyarankan secara selektif iaitu:

“...boleh tambah program dan kempen lagi ...”” (2 Jun 2021/TB: 69]

Cadangan mekanisme kempen ini telah ditegaskan oleh peserta 3 (lelaki, umur 18) seperti berikut:

“...mengadakan kempen macam tu...buat mesyuarat untuk semua orang...bagi semua orang tahu dadah dan bahayanya ....Kita boleh guna watsap, facebook ...kita pun boleh post...." (3 Jun 2021/TB: 63-65] 
DOI: https://doi.org/10.47405/aswj.v6i5.187

Pandangan senada turut dilontarkan oleh peserta 4 (lelaki, umur 18):

“kena kuatkan kempen lagi la...” (4 Jun 2021/TB: 55]

Perihal ini juga selari dengan peserta 5 (lelaki, umur 18) yang padat dan ringkas:

“...emmm..buat program anti dadah macam tu...” (5 Jun 2021/TB: 60-61]

Kenyataan peserta sebelum ini disokong oleh peserta 6 (lelaki, umur 17) dengan cadangan kempen melalui media cetak:

\begin{abstract}
"Macam buat sesuatu...tu ...macam buat perjumpaan..macam sampaikan pesanan pengetahuan dadah ...Media cetak boleh sampaikan maklumat...saya ingat dua cara ini sahaja ....dapat sampai mesej tu" (6 Jun 2021/TB: 73- 75]
\end{abstract}

Berdasarkan dapatan analisis soalan 12, lima peserta kajian (83\%) menyatakan kempen antidadah yang agresif serta efektif adalah satu instrumen yang relevan dan tepat bagi menyalurkan pengetahuan dadah dan kesannya kepada remaja bagi memastikan gejala penyalahgunaan dadah dapat dituntas secara kolektif sehingga ke peringkat akar umbi.

\title{
Perbincangan dan Implikasi Kajian
}

Secara keseluruhannya, dalam konteks kajian ini, perbincangan secara menyeluruh difokuskan kepada 2 komponen penting iaitu 'celik akal', dadah dan kesannya serta sumber maklumat berkenaan. Lensa perbincangan dicapahkan secara terperinci serta selektif agar kefahaman yang mendalam mengenai isuisu ditemui dan diketengahkan dalam kajian ini agar dapat diperihal dan dijelaskan dengan lebih bermakna untuk mencari prakarsa bagi mendepani isu penyalahgunaan dadah dengan lebih konkrit daripada dapatan kajian yang diperolehi daripada kajian lepas dapat dirumuskan bagi menjawab ke semua soalan kajian yang diketengahkan adalah hampir sama iaitu memfokuskan kepada faktor kurangnya celik akal yang melibatkan golongan remaja terhadap dadah dan kesannya serta bagaimana sumber untuk memperoleh maklumat tersebut. Perspektif persoalan kurang 'celik akal' terhadap dadah dan kesannya dalam kajian ini merangkumi maklumat mengenai bahan tersebut secara umum dan khusus. Ianya turut mencakupi aspek pengertian bahan, kefahaman mengenai tindak balas bahan terhadap tubuh badan manusia, kesan penyalahgunaan bahan kepada kehidupan iaitu fizikal mahupun mental dan saluran penyebaran fakta bahan yang tepat lagi sahih merangkumi penjanaan minda landskap dunia remaja.

\section{Kesimpulan}

Maklumat pengetahuan dadah fungsi kepada celik akal yang ingin disalurkan berlandaskan kefahaman "di mana kita sekarang" dan bagaimana untuk sampai ke "tahap yang kita mahukan" bagi memenuhi keperluan semasa serta pandangan komuniti. Dalam konteks ini, pelbagai kempen, penjenamaan program penggubalan tema, strategi dan pelan tindakan dilaksanakan bagi memastikan setiap insan yang bergelar warganegara Malaysia memperoleh pengetahuan dadah yang mempunyai fakta tepat serta betul dengan harapan merealisasikan negara bebas dadah dalam konteks acuan kita sendiri. Namun demikian, dengan perangkaan mereka yang terlibat dengan penagihan dadah yang semakin meningkat saban tahun, sudah tentu ianya memerlukan anjakan transformasi komprehensif kepada pendidikan pencegahan yang sedia ada bagi merealisasikan sesuatu yang menjadi impian selama ini, iaitu ke arah melahirkan generasi warisan negara yang tidak lagi terpalit dengan kebejatan sosial khususnya penyalahgunaan dadah. 


\section{Rujukan}

AADK (2020). Penyalah Guna dan Penagih Dadah serta bahan, 2020 - Sumber Data:AADK, Bahagian Dasar Perancangan dan Pendidikan Ibu Pejabat AADK Malaysia Agensi Antidadah Kebangsaan Malaysia.

Agensi Antidadah Kebangsaan. (2017). Buku Maklumat Dadah, Agensi Antidadah Kebangsaan, Kajang, Selangor, Akta Penagih Dadah ( Rawatan dan Pemulihan) 1983 (Akta 283), 2012:8.

Berita Sinar Harian (2020), punca utama penggunaan bahan ini adalah kurang 'celik akal' (Pengetahuan) mengenai bahaya dadah,penyebab jumlah penagih baharu di negara ini semakin meningkat pada setiap tahun.

Creswell, J.W. (2014). Educational Research: Planning, Conducting and Evaluating Quantitative and Qualitative Research . Upper Saddle River, NJ: Merill Prentice Hall.

Lonnie Embleton. (2012). Knowledge, Attitudes and Substance Use Practices Among Street Children in Western Kenya: Substance Use Misuse, 47(11), 1234 - 1247.

Merriam, S.B. (2009). Qualitative Research and Case Study Applications in Education. San Francisco: Jessey-Bass Publisher.

Monica Wanjiku Njoroge. (2017). Knowledge, Attitude and Practices on Substance Use Disorders by University Students: A Review of Literature. Journal Alcoholism \& Drug Dependence, 5(6), 291.

Nahid Geramian, Shohreh Akhavan, Leila Gharat, Afsaneh Malekpour Tehrani \& Ziba Farajzadegan. (2012). Determinants of Drug Abuse in High School Students and their Related Knowledge and Attitude. Iranian Journal Public Health, 62(3).

National Institute on Drug Abuse. (2014). Preventing Drug Abuse Among Children and Adolescents. NIH Publication.

Noorazleen Mohamad Nor. (2015). Kerinduan atau Ketagihan Terhadap Dadah: Punca Belia Kecundang dan Kembali Menagih: Universiti Tunku Abdul Rahman. Ipoh, Perak.

Nor Azri Ahmad, Rozmi Ismail, Fauziah Ibrahim \& Salina Nen. (2017). Pengaruh Faktor Individu ,Keluarga dan Persekitaran Sosial Terhadap Tingkah Laku Penyalahgunaan Bahan dalam Kalangan Remaja. Akademika, 87(1), 7-16.

Yahya Muhammed Bah. (2018). Drug Abuse Among Street Children. Mathews Journal of Case Report, $3(1), 038$. 